\title{
PENGARUH SISTEM PENGENDALIAN INTERN DAN KAPASITAS SUMBER DAYA MANUSIA TERHADAP KUALITAS INFORMASI LAPORAN KEUANGAN DENGAN FAKTOR EKSTERNAL SEBAGAI VARIABEL MODERATING
}

\author{
Reni Yendrawati \\ Fakultas Ekonomi, Universitas Islam Yogyakarta \\ e-mail: reni@fe.uii.ac.id
}

\begin{abstract}
This study aims to determine moderating effect of external factors on the relationship between internal control systems and human resource capacity on the quality of financial reporting information. Data collection was conducted using questionnaire to all financial management at the Department of Social Special Region in Yogyakarta. This study used 44 people as respondents. The results showed that the internal control system negatively affect the quality of financial statement information. In addition, the capacity of human resources has a positive effect on the quality of financial reporting information and external factors may moderate the relationship between internal control systems and the quality of financial reporting information. However, this study does not support the hypothesis that external factors may moderate the effect of human resources on the quality of financial reporting information.
\end{abstract}

Keywords: system of internal control, human resource capacity and the quality of financial reporting information.

\begin{abstract}
Abstraksi
Penelitian ini bertujuan untuk mengetahui pengaruh sistem pengendalian intern dan kapasitas sumber daya manusia terhadap kualitas informasi laporan keuangan dengan faktor eksternal sebagai variabel moderating. Pengumpulan data dilakukan dengan memberikan kuesioner kepada semua pengelola keuangan pada Dinas Sosial Daerah Istimewa Yogyakarta. Responden penelitian berjumlah 44 orang. Hasil penelitian menunjukkan bahwa sistem pengendalian intern berpengaruh negatif terhadap kualitas informasi laporan keuangan, kapasitas sumber daya manusia berpengaruh positif terhadap kualitas informasi laporan keuangan dan faktor eksternal dapat memoderasi pengaruh sistem pengendalian intern terhadap kualitas informasi laporan keuangan. Sedangkan faktor eksternal tidak dapat memoderasi pengaruh sumber daya manusia terhadap kualitas informasi laporan keuangan.
\end{abstract}

Kata kunci: sistem pengendalian intern, kapasitas sumber daya manusia dan kualitas informasi laporan keuangan.

\section{PENDAHULUAN}

\section{Latar Belakang Masalah}

Pemerintah sudah melakukan reformasi tentang pengelolaan keuangan dengan mengeluarkan Undang-Undang Nomor 17 Tahun 2003 tentang Keuangan Negara yang mensyaratkan bentuk dan isi laporan pertanggungjawaban pelaksanaan Anggaran Pendapatan dan Belanja Daerah (APBN) atau Anggaran Pendapatan dan Belanja Daerah (APBD) disusun dan disajikan dengan standar akuntasi pemerintahan yang ditetapkan oleh pemerintah. Tujuan dari reformasi akuntansi dan administrasi sektor publik adalah akuntabilitas dan transparansi pengelolaan keuangan pemerintah pusat maupun daerah. Akuntabilitas dapat diartikan sebagai bentuk kewajiban mempertanggungjawabkan keberhasilan atau kegagalan 
pelaksanaan misi organisasi dalam mencapai tujuan dan sasaran yang telah ditetapkan sebelumnya, melalui suatu media pertanggungjawaban yang dilaksanakan secara periodik.

Fenomena laporan keuangan pemerintah di Indonesia merupakan sesuatu hal yang menarik untuk dikaji lebih lanjut. Dari berbagai tulisan yang berhasil didownload dari internet, ternyata di dalam laporan keuangan pemerintah masih banyak disajikan data-data yang tidak sesuai. Selain itu juga masih banyak penyimpangan-penyimpangan yang berhasil ditemukan oleh Badan Pemeriksa Keuangan dalam pelaksanaan audit laporan keuangan pemerintah (Indriasari 2011).

Temuan-temuan yang ada pada Pengelolaan Keuangan yang disajikan oleh pemerintah banyak terjadi penyimpangan dalam mengelola keuangan terutama terdapat pada APBN dan APBD. Belum lama ini BPK (Badan Pemeriksa Keuangan) menemukan banyak kejanggalan dalam pengelolaan keuangan Negara di berbagai instansi. Temuan tersebut merupakan hasil audit yang digelar badan ini selama semester kedua tahun lalu terhadap pemerintah pusat dan daerah, serta Badan Umum Milik Negara dan daerah. Potensi kerugian negara tersebut merupakan buntut ketidakpatuhan terhadap perundangundangan dan sistem pengendalian intern (Kontan News 2010).

Berdasar data dari BPK permasalahan masih di dominasi tentang lemahnya sistem pengendalian intern pada pemerintah daerah/pusat. Masih begitu banyak ditemukan ketidakpatuhan karyawan dan manajer dalam hal sistem pengendalian intern yang ada pada perusahaan/pemerintah daerah. Begitu pula dengan pengelolaan keuangan daerah yang masih sangat kurang, hal ini menjadikan kualitas laporan keuangan juga menurun serta dapat juga memberikan dampak pada keandalan dan ketepatan waktu terhadap laporan kuangan. Masih banyak terjadi kejanggalan-kejanggalan yang terjadi pada saat auditor dan BPK memeriksa sebuah laporan keuangan sebuah perusahaan atau pada pemerintah daerah.

Secara umum, hasil pemeriksaan atas LKPD tahun 2011 menunjukan perbaikan kualitas penyajian laporan keuangan dibanding LKPD tahun 2010 yang diperiksa pada semester I tahun 2011. Jumlah LKPD yang memperoleh opini WTP mengalami peningkatan dari 34 menjadi 67. Meskipun jumlah LKPD yang memperoleh WTP mengalami peningkatan, namun dibandingkan dengan jumlah seluruh LKPD, LKPD yang memperoleh opini WTP tersebut relatif masih kecil, yaitu 16 persen. BPK berharap agar pemerintah daerah perlu meningkatkan kualitas penyajian LKPD sehingga dapat memperoleh opini yang lebih baik di masa yang akan datang. BPK juga berharap agar pemerintah daerah melakukan perbaikan dengan menindaklanjuti rekomendasi BPK, antara lain, berkoordinasi dengan bank dalam mengelola rekening bendahara pengeluaran, meningkatkan pengelolaan, penatausahaan, pengendalian, dan pengawasan persediaan (Viva News 2012).

Semua Pemda menginginkan opini WTP dan untuk memperoleh opini tersebut mereka melakukan berbagai cara, baik dengan memperbaiki kualitas SDM dan meningkatkan fasilitas pendukung untuk akuntansi dan pelaporan keuangannya ataupun melalui kerja sama dengan konsultan yang berasal dari Pemerintah (seperti BPKP) dan swasta. Beberapa daerah berhasil mencapai target: memperoleh opini WTP ini.

Dari fenomena tersebut dapat dinyatakan bahwa laporan keuangan pemerintah masih belum seluruhnya memenuhi kriteria keterandalan, kepatuhan dan ketepatwaktuan (timeliness). Mengingat bahwa keterandalan dan ketepatwaktuan merupakan dua unsur nilai informasi yang penting terkait dengan pengambilan keputusan berbagai pihak, peneliti tertarik untuk meneliti hal apa yang mungkin mempengaruhi keterandalan dan ketepatwaktuan pelaporan keuangan pemerintah.

Menurut penelitian terdahulu yang diteliti oleh Sukmaningrum (2012) mengenai analisis faktor-faktor yang mempengaruhi kualitas informasi laporan keuangan menyatakan bahwa sistem pengendalian intern berpengaruh positif terhadap kualitas informasi laporan keuangan pemerintah daerah. Hal ini menunjukan sistem pengendalian intern ber- 
pengaruh secara signifikan terhadap kualitas informasi laporan keuangan pemerintah daerah. Sistem pengendalian internal telah memenuhi fungsinya dalam hal memberikan keyakinan memadai tentang (1) keandalan laporan keuangan, (2) kepatuhan terhadap hukum dan perundang-undangan, (3) efektifitas dan efisiensi operasi. Berdasarkan kesimpulan dari penelitian ini menunjukkan bahwa kompetensi sumber daya manusia yang diproksikan dengan pemahaman staf, interaksi antara sumber daya manusia dengan sistem, kontrol terhadap sumber daya manusia, dan pendidikan serta training tidak berpengaruh terhadap kualitas informasi laporan keuangan pemerintah daerah. Kelemahan dari penelitian ini adalah variabel bebas yang dimasukkan dalam penelitian ini masih terbatas.

Menurut penelitian Indriasari (2011), kapasitas sumber daya manusia tidak mempunyai pengaruh yang signifikan terhadap keterandalan pelaporan keuangan pemerintah daerah. Ketidaksignifikanan ini mungkin disebabkan kondisi kapasitas sumber daya manusia di sub bagian akuntansi/tata usaha keuangan yang belum mendukung. Penelitian tersebut menunjukkan bahwa pengendalian intern menunjukkan berpengaruh positif signifikan terhadap keterandalan pelaporan keuangan pemerintah daerah. Temuan ini juga mendukung berbagai literatur yang menjelaskan tentang tujuan dari pengendalian intern yaitu memberikan keyakinan yang memadai mengenai pencapaian tujuan pemerintah daerah yang tercermin dari keterandalan laporan keuangan. Kelemahan dari penelitian ini adalah keterbatasan yang dirasa cukup mengganggu dalam penelitian ini adalah model yang digunakan. Model yang digunakan dalam penelitian ini bukanlah model yang telah teruji di dalam penelitian sebelumnya. Model penelitian ini dibangun atas dugaan yang kuat akan hubungan variabel yang dihipotesiskan. Tujuan dari penelitian ini adalah: a) mengetahui bagaimana sistem pengendalian intern dan kapasitas sumber daya manusia berpengaruh pada kualitas laporan keuangan; (b) mengetahui bagaimana faktor eksternal dapat mempengaruhi hubungan sistem pengendalian intern dan kapasitas sumber daya manusia terhadap kualitas informasi laporan keuangan.

\section{TINJAUAN PUSTAKA DAN PERUMUSAN HIPOTESIS Laporan Keuangan}

Laporan keuangan merupakan catatan informasi keuangan suatu perusahaan pada suatu periode akuntansi yang dapat digunakan untuk menggambarkan kinerja perusahaan tersebut. Ciri khas yang membuat informasi dalam laporan keuangan berguna bagi pemakai disebut dengan sifat atau karakteristik kualitatif. Sifat kualitatif laporan keuangan tersebut di antaranya meliputi halhal sebagai berikut.

a. Dapat dipahami, artinya laporan keuangan mudah untuk dipahami oleh pemakai.

b. Relevan, artinya laporan keuangan harus sesuai dengan tujuan operasional perusahaan dan memenuhi kebutuhan pemakai dalam proses pengambilan keputusan.

c. Materialitas, artinya suatu laporan atau fakta dipandang material apabila kelalaian dalam mencantumkan atau kesalahan mencatat informasi dapat mempengaruhi keputusan ekonomi pemakai dengan analisis bahwa keadaan lain sebagai bahan pertimbangan lengkap.

d. Keandalan (reliable), artinya informasi laporan keuangan harus bebas dari pengertian yang menyesatkan, kesalahan material, dan dapat diandalkan pemakainya sebagai penyajian yang tulus dan jujur (faithful representation).

e. Penyajian jujur, artinya informasi akuntansi harus menggambarkan kejujuran transaksi serta peristiwa lain yang seharusnya disajikan atau secara wajar dapat diharapkan untuk disajikan.

f. Substansi mengungguli bentuk, artinya jika dimaksudkan untuk menyajikan informasi dengan jujur, maka transaksi perlu dicatat dan disajikan sesuai dengan substansi dan realitas ekonomi, bukan hanya bentuk hukumnya.

g. Netralitas, artinya informasi akuntansi harus diarahkan pada kebutuhan umum 
pemakai, tidak bergantung pada kebutuhan dan keinginan pihak tertentu.

h. Pertimbangan sehat, artinya informasi yang disajikan mengandung unsur kehatihatian pada saat melakukan perkiraan dalam kondisi ketidakpastian.

i. Kelengkapan, artinya informasi dalam laporan keuangan harus lengkap dalam batasan materialitas dan biaya.

j. Dapat dibandingkan, artinya informasi akuntansi harus dapat dibandingkan dengan laporan periode sebelumnya serta dapat dibandingkan dengan perusahaan lain yang sejenis.

\section{Sistem Pengendalian Intern}

Menurut Ikatan Akuntan Publik Indonesia (2011) sistem pengendalian intern merupakan suatu proses yang dijalankan oleh dewan komisaris, manajemen dan personil lain yang didesain untuk memberikan keyakinan memadai tentang pencapaian tiga golongan tujuan berikut ini: a) Keandalam pelaporan keuangan. b) Efektifitas dan efisiensi operasi. c) Kepatuhan terhadap hukum dan peraturan yang berlaku.

Manajemen bertanggungjawab untuk merancang dan menerapkan lima unsur sistem pengendalian intern (elements of internal control) untuk mencapai tiga tujuan pengendalian intern. Unsur-unsur tersebut menurut Agoes (2012) adalah lingkungan pengendalian, penaksiran risiko, aktifitas pengendalian, informasi dan komunikasi dan pemantauan.

Pengendalian intern pemerintahan diatur oleh Peraturan Pemerintah No 60 tahun 2008 tentang sistem pengendalian intern pemerintah. Pada pasal 1 dijelaskan:

1. Sistem Pengendalian Intern adalah proses yang integral pada tindakan dan kegiatan yang dilakukan secara terus menerus oleh pimpinan dan seluruh pegawai untuk memberikan keyakinan memadai atas tercapainya tujuan organisasi melalui kegiatan yang efektif dan efisien, keandalan pelaporan keuangan, pengamanan aset negara, dan ketaatan terhadap peraturan perundang-undangan.
2. Sistem Pengendalian Intern Pemerintah, yang selanjutnya disingkat SPIP, adalah Sistem Pengendalian Intern yang diselenggarakan secara menyeluruh di lingkungan pemerintah pusat dan pemerintah daerah.

3. Pengawasan Intern adalah seluruh proses kegiatan audit, review, evaluasi, pemantauan, dan kegiatan pengawasan lain terhadap penyelenggaraan tugas dan fungsi organisasi dalam rangka memberikan keyakinan yang memadai bahwa kegiatan telah dilaksanakan sesuai dengan tolak ukur yang telah ditetapkan secara efektif dan efisien untuk kepentingan pimpinan dalam mewujudkan tata kepemerintahan yang baik.

4. Badan Pengawasan Keuangan dan Pembangunan, yang selanjutnya disingkat BPKP, adalah aparat pengawasan intern pemerintah yang bertanggung jawab langsung kepada presiden.

5. Inspektorat Jenderal atau nama lain yang secara fungsional melaksanakan pengawasan intern adalah aparat pengawasan intern pemerintah yang bertanggung jawab langsung kepada menteri/pimpinan lembaga.

6. Inspektorat Provinsi adalah aparat pengawasan intern pemerintah yang bertanggung jawab langsung kepada gubernur.

7. Inspektorat Kabupaten/Kota adalah aparat pengawasan intern pemerintah yang bertanggung jawab langsung kepada bupati/walikota.

8. Kementerian negara adalah organisasi dalam Pemerintahan Republik Indonesia yang dipimpin oleh menteri untuk melaksanakan tugas dalam bidang tertentu.

9. Lembaga adalah organisasi non-kementrian negara dan instansi lain pengguna anggaran yang dibentuk untuk melaksanakan tugas tertentu berdasarkan UndangUndang Dasar Negara Republik Indonseia tahun 1945 atau peraturan perundangundangan lainnya.

10. Pemerintah daerah adalah gubernur, bupati, walikota, dan perangkat daerah sebagai unsur penyelenggara pemerintahan daerah. 
11. Instansi Pemerintah adalah unsur penyelenggara pemerintahan pusat atau unsur penyelenggara pemerintahan daerah.

\section{Kapasitas Sumber Daya Manusia}

Kapasitas sumber daya manusia adalah kemampuan seseorang atau individu, suatu organisasi (kelembagaan), atau suatu sistem untuk melaksanakan fungsi-fungsi atau kewenangannya untuk mencapai tujuannya secara efektif dan efisien. Kapasitas harus dilihat sebagai kemampuan untuk mencapai kinerja, untuk menghasilkan keluaran-keluaran (outputs) dan hasil-hasil (outcomes).

\section{Faktor Eksternal}

Lingkungan eksternal organisasi adalah segala sesuatu yang berada di luar organisasi namun mempengaruhi atau berpengaruh secara langsung terhadap organisasi. Lingkungan Eksternal adalah lingkungan yang berada di luar organisasi saling mempertukarkan sumber dayanya dengan organisasi tersebut dan tergantung satu sama lain, perusahaan yang berpengaruh tidak langsung terhadap kegiatan perusaan. Lingkungan eksternal meliputi variabel-variabel di luar organisasi yang dapat berupa tekanan umum dan tren di dalam lingkungan sosial ataupun faktor-faktor spesifik yang beroperasi di dalam lingkungan kerja (industri) organisasi. Variabel-variabel eksternal ini terbagi menjadi dua jenis, yaitu ancaman dan peluang. Lingkungan eksternal terdiri atas unsur-unsur di luar organisasi yang sebagian besar tidak dapat dikendalikan dan berpengaruh dalam pembuatan keputusan oleh manajer. Organisasi mendapatkan masukanmasukan yang dibutuhkan, seperti bahan baku, dana tenaga kerja dan energi dari lingkungan eksternal, mentransformasikan menjadi produk dan jasa, kemudian memberikan sebagai keluaran-keluaran kepada lingkungan eksternal.

\section{Perumusan Hipotesis}

Fenomena yang terjadi dalam laporan keuangan hasil dari pemeriksaan BPK menemukan masih banyaknya penyimpangan dan ke- bocoran, dan kurangnya kepatuhan para karyawan akan sistem pengendalian intern yang sudah diberlakukan di dalam pemerintah daerah. BPK juga masih sering memberikan opini "tidak wajar/disclaimer" itu semua dikarenakan oleh lemahnya sistem pengendalian intern (Badan Pemeriksa Keuangan 2011).

Menurut Arfianti (2011) Pengendalian intern merupakan suatu cara untuk mengarahkan, mengawasi, dan mengukur sumber daya suatu organisasi, serta berperan penting dalam pencegahan dan pendeteksian penggelapan (fraud). Jika sistem pengendalian intern lemah maka akan banyak ditemukan kasus penggelapan akan aset daerah, dan itu akan merugikan negara secara keselurahan. Menurut Yendrawati (2012) efektifitas pengendalian intern dapat mencegah kecurangan akuntansi, sehingga kualitas informasi laporan keuangan dapat ditingkatkan. Yendrawati (2013) menambahkan kualitas pengendalian internal berpengaruh negatif terhadap motivasi melakukan kecurangan, sehingga jika semakin bagus kualitas pengendalian intern, maka tingkat kecurangan semakin rendah.

Dari uraian diatas, peneliti ingin meneliti lebih lanjut cara kerja sistem pengendalian intern karena terlalu banyaknya kasus yang terjadi atas laporan keuangan dikarenakan oleh lemahnya sistem pengendalian intern.

H1: Sistem pengendalian intern berpengaruh positif terhadap kualitas informasi laporan keuangan.

PP Nomor 105 Tahun 2000 dan Kepmendagri Nomor 29 Tahun 2002 telah membawa perubahan besar dan memberikan pendekatan baru dalam pengelolaan keuangan daerah. Perubahan yang mendasar dalam PP Nomor 105 Tahun 2000 adalah terkait dengan perubahan dalam sistem penganggaran, baik proses penganggarannya maupun bentuk dan struktur APBD. Perubahan tersebut merupakan suatu perubahan yang bersifat paradigmatik, sementara perubahan yang lebih bersifat pragmatik dan teknis operasional diatur dalam Kepmendagri Nomor 29 Tahun 2002, 
yaitu terkait dengan penatausahaan keuangan daerah. Perubahan itu sudah sampai pada teknik akuntansinya yang meliputi perubahan dalam pendekatan sistem akuntansi dan prosedur pencatatan, dokumen dan formulir yang digunakan, fungsi-fungsi otorisasi untuk tujuan sistem pengendalian intern, laporan, serta pengawasan (Forum Dosen Akuntansi Sektor Publik 2006).

Indriasari (2011) membuktikan bukti empiris tentang kapasitas sumberdaya manusia berpengaruh positif terhadap keterpautan dan keterandalan informasi laporan keuangan pemerintah daerah kota Palembang dan kabupaten Ogan Hilir Provinsi Sumatra Selatan. Namun masih banyak masalah yang terjadi pada sumber daya manusia, misalnya kurangnya pemahaman mereka akan akuntansi, dan kurangnya pemahaman mereka tentang kualitas laporan keuangan yang dihasilkan.

Berdasarkan uraian di atas, penelitian ini dimaksudkan untuk meneliti kembali hubungan antara kapasitas sumber daya manusia dan kualitas laporan keuangan.

H2: Kapasitas Sumber Daya Manusia berpengaruh positif terhadap kualitas informasi laporan keuangan daerah.

Lingkungan eksternal organisasi adalah segala sesuatu yang berada di luar organisasi namun mempengaruhi atau berpengaruh secara langsung terhadap organisasi. Lingkungan Eksternal adalah lingkungan yang berada di luar organisasi saling mempertukarkan sumber dayanya dengan organisasi tersebut dan tergantung satu sama lain, perusahaan yang berpengaruh tidak langsung terhadap kegiatan perusahaan. Dinamika yang terjadi dalam suatu pemerintah daerah dan lemahnya sistem pengendalian intern dapat terjadi pula karena faktor-faktor eksternal yang mempengaruhi. Dari uraian di atas dirumuskan hipotesis ketiga sebagai berikut:

H3a: Faktor Eksternal memoderisasi pengaruh positif sistem pengendalian intern terhadap kualitas informasi laporan keuangan.

H3b: Faktor Eksternal memoderisasi pengaruh positif kapasitas sumber daya manusia terhadap kualitas informasi laporan keuangan.

\section{METODA PENELITIAN Populasi dan Teknik Pengambilan Sampel}

Populasi yang digunakan adalah Pegawai Dinas Sosial Daerah Istimewa Yogyakarta termasuk UPTD-UPTD nya. Kriteria sampel adalah semua pengelola keuangan pada Dinas Sosial Daerah Istimewa Yogyakarta dan UPTD-UPTD di lingkungan Dinas Sosial Daerah Istimewa Yogyakarta.

\section{Variabel Penelitian dan Definisi Operasionel Variabel Kualitas informasi laporan keuangan}

Kualitas informasi laporan keuangan daerah diukur dengan delapan indikator, yaitu: (1) manfaat dari laporan keuangan yang dihasilkan, (2) ketepatan pelaporan laporan keuangan, (3) kelengkapan informasi yang disajikan, (4) Penyajian secara jujur, (5) Isi laporan keuangan dapat diverifikasi, (6) Keakuratan informasi yang disajikan, (7) Isi laporan keuangan dapat dibandingkan dengan periode sebelumnya (8) kejelasan penyajian informasi dalam laporan keuangan. Kriteria tersebut mengacu pada penelitian yang dilakukan oleh Sukmaningrum (2012).

\section{Sistem Pengendalian Intern}

Variabel sistem pengendalian intern ini dapat diukur dengan instrument yang dibuat oleh $\mathrm{Xu}$, et al. (2003) dan dikembangkan oleh Choirunisah (2008). Terdapat empat indikator, yaitu: (1) Integritas data, (2) Ketepatan input dan posting data, (3) Prosedur otorisasi dokumen transaksi, (4) Tersimpannya dokumen sumber data, (5) Pembagian tanggungjawab, (6) Penentuan kebijakan dan standar akuntansi, (7) Implementasi kebijakan dan standar

\section{Kapasitas Sumber daya Manusia}

$\mathrm{Xu}$, et al. (2003) mengatakan bahwa interaksi antara sumber daya manusia dan sistem adalah isu penting dalam implementasi sistem yang akan mempengaruhi kualitas informasi 
akuntansi. Variabel kompetensi sumber daya manusia diukur dengan instrumen yang dibuat oleh Xu, et al. (2003). Terdapat empat indikator, yaitu: (1) Pemahaman terhadap peraturan dan standar, (2) Interaksi dengan sistem, (3) Kontrol terhadap SDM, (4) Pendidikan dan training,

\section{Faktor Eksternal}

Faktor eksternal adalah faktor-faktor diluar organisasi yang tidak daat dikendalikan. Variabel faktor eksternal ini dapat diukur dengan instrumen yang dibuat oleh $\mathrm{Xu}$, et al. (2003). Terdapat empat indikator, yaitu: (1) kemajuan IT, (2) Perkembangan website dan teknologi internet, (3) Perubahan standar pelaporan, (4) Perubahan regulasi pemerintah secara global.

\section{Metoda Analisis \\ Model regresi linear}

Pada uji hipotesis peneliti menggunakan MRA (Moderated Regression Analysis). MRA merupakan uji interaksi atau sering disebut dengan Moderated Regresion Analysis (MRA) merupakan aplikasi khusus dimana dalam persamaan regresinya mengandung unsur interaksi (perkalian dua atau lebih variabel independen) (Ghozali 2011) dengan rumus persamaan sebagai berikut:

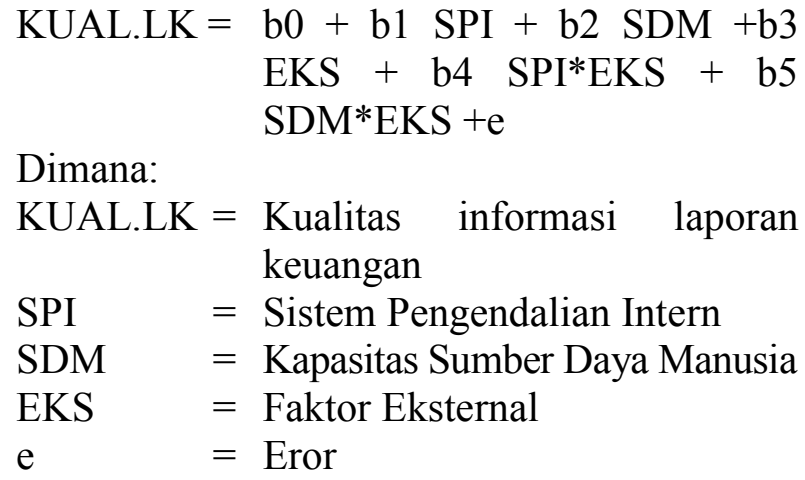

\section{Uji Hipotesis}

Uji hipotesis menggunakan uji statistic $\mathrm{T}$. Hipotesis akan diuji dengan menggunakan tingkat signifikansi $(\alpha)$ sebesar 5 persen atau 0,05 .

\section{HASIL DAN PEMBAHASAN Gambaran Umum Responden}

Berdasarkan data yang diperoleh dari hasil penelitian, dapat dijelaskan mengenai karakteristik responden. Karakteristik responden dapat dilihat melalui demografi responden. Demografi tersebut digunakan untuk mengetahui gambaran umum tentang pengelola keuangan yang bekerja di Dinas Sosial DIY. Demografi responden dapat dilihat pada tabel 1.

Kuesioner disebar sesuai dengan jumlah pengelola keuangan di masing-masing tempat. Semua kuesioner yang disebar kembali dan dapat diolah.

Tabel 1: Daftar Distribusi Kuesioner

\begin{tabular}{|c|c|c|c|c|}
\hline No & Unit kerja & $\begin{array}{c}\text { Jumlah } \\
\text { yang } \\
\text { dibagikan }\end{array}$ & $\begin{array}{c}\text { Jumlah } \\
\text { yang tidak } \\
\text { kembali }\end{array}$ & $\begin{array}{c}\text { Jumlah } \\
\text { yang dapat } \\
\text { digunakan }\end{array}$ \\
\hline 1 & Dinas social & 13 & 0 & 13 \\
\hline 2 & Panti Sosial Tuna Werda (PSTW) & 6 & 0 & 6 \\
\hline 3 & Panti Sosial Asuhan Anak (PSAA) & 4 & 0 & 4 \\
\hline 4 & Panti Sosial Karya Wanita (PSKW) & 4 & 0 & 4 \\
\hline 5 & Panti Sosial Bina Remaja (PSBR) & 4 & 0 & 4 \\
\hline 6 & Panti Sosial Bina Karya (PSBK) & 4 & 0 & 4 \\
\hline 7 & Panti Sosial Permadi Putra (PSPP) & 5 & 0 & 5 \\
\hline 8 & $\begin{array}{l}\text { Balai Rehabilitasi Terpadu Penyandang Difabel } \\
\text { (BRTPD) }\end{array}$ & 4 & 0 & 4 \\
\hline & Total & 44 & 0 & 44 \\
\hline
\end{tabular}




\section{Hasil Uji Hipotesis}

Tabel 2: Uji Hipotesis

\begin{tabular}{lccl}
\hline \multicolumn{1}{c}{ Keterangan } & Koefisien & Signifikan & \multicolumn{1}{c}{ Kesimpulan } \\
\hline SPI & $-1,489$ & 0,000 & Tidak didukung \\
SDM & 1,189 & 0,026 & Didukung \\
SPI*EKS & 0,414 & 0,000 & Didukung \\
SDM*EKS & $-1,191$ & 0,103 & Tidak didukung \\
\hline
\end{tabular}

Tabel 3: Uji Koefisien Determinasi

\begin{tabular}{rrrrr}
\hline Model & R & R Square & Adjusted R Square & Std. Error of the Estimate \\
\hline 1 & $.769(\mathrm{a})$ & .591 & .537 & .25035 \\
\hline
\end{tabular}

Sebelum dilakukan uji hipotesis, terlebih dahulu telah dilakukan uji validitas dan reliabilitas, dan hasilnya terbukti valid dan reliabel. Hasil uji asumsi klasik juga terbukti lolos dari uji asumsi klasik. Hasil uji hipotesis dapat dilihat pada Tabel 2. Sedangkan untuk koefisien determinasi dapat dilihat pada tabel 3 .

Tabel 3 menunjukkan bahwa besarnya nilai adjusted R2 adalah 0,537 atau $53,7 \%$. Hal ini berarti variabilitas variabel independen dalam penelitian ini, yakni sistem pengendalian intern dan kapasitas sumber daya manusia serta faktor eksternal dapat menjelaskan variabel dependennya, yaitu kualitas informasi laporan keuangan sebesar 53,7\%.

\section{Pembahasan}

$\mathrm{H}_{1}$ : Sistem pengendalian intern berpengaruh positif terhadap kualitas informasi laporan keuangan.

Hipotesis pertama $\left(\mathrm{H}_{1}\right)$ yang menyatakan bahwa sistem pengendalian intern berpengaruh positif terhadap kualitas informasi laporan keuangan tidak terbukti. Walaupun sistem pengendalian intern yang telah ditetapkan sudah bagus, tetapi belum diterapkan secara efektif menyebabkan informasi laporan keuangan yang dihasilkan kurang tepat. Penelitian ini sesuai dengan penelitian Choirunisah (2008) yang menemukan internal kontrol tidak berpengaruh signifikan terhadap kualitas laporan keuangan yang dihasilkan oleh sistem akuntansi instansi.

$\mathrm{H}_{2}$ : Kapasitas sumber daya manusia berpengaruh positif terhadap kualitas informasi laporan keuangan.
Hipotesis kedua $\left(\mathrm{H}_{2}\right)$ menyatakan kapasitas sumber daya manusia berpengaruh positif terhadap kualitas informasi laporan keuangan terbukti. Hal ini menunjukkan bahwa semakin bagus kapasitas sumber daya manusia, maka kualitas informasi laporan keuangan juga semakin bagus. Menilai kapasitas sumber daya manusia dalam melaksanakan suatu fungsi, termasuk akuntansi, dapat dilihat dari level of responsibility sumber daya tersebut. Tanggungjawab sumber daya manusia dapat dilihat dalam diskripsi jabatan. Diskripsi jabatan merupakan dasar untuk melaksanakan tugas dengan baik. Pemisahan tugas yang dilakukan manajemen dapat mengurangi terjadinya kecurangan antara karyawan yang satu dengan karyawan yang lain walaupun yang bekerja dalam satu bidang.

Hasil penelitian ini mendukung penelian $\mathrm{Xu}$, et.al. (2003) dan Choirunisah (2008) yang membuktikan bahwa kapasitas sumber daya manusia berpengaruh positif terhadap kualitas informasi laporan keuangan.

H3a: Faktor Eksternal memoderisasi pengaruh positif sistem pengendalian intern terhadap kualitas informasi laporan keuangan.

Faktor eksternal memoderasi pengaruh positif sistem pengendalian intern terhadap kualitas informasi laporan keuangan terbukti. Hasil ini dapat disimpulkan bahwa faktor eksternal dapat menyebabkan sistem pengendalian intern berpengaruh positif signifikan terhadap kualitas informasi lapaoran keuangan. Faktor eksternal misalnya: kemajuan teknologi informasi, perubahan standar pelaporan, perubahan 
peraturan dari pemerintah justru dengan pengendalian intern yang bagus dapat menantang karyawan untuk bekerja dengan lebih semangat untuk menyusun laporan keuangan dengan sebaik-baiknya, sehingga kualitas informasi laporan keuangan dapat semakin bagus.

H3b: Faktor Eksternal memoderasi pengaruh positif kapasitas sumber daya manusia terhadap kualiatas infromasi laporan keuangan

Faktor eksternal memoderasi pengaruh positif kapasitas sumber daya manusia terhadap kualitas informasi laporan keuangan tidak terbukti. Hasil ini dapat disimpulkan bahwa faktor eksternal tidak berpengaruh positif terhadap kapasitas sumber daya manusia, hal ini kemungkinan terjadi karena adanya tekanan umum dan budaya dalam suatu lingkungan kerja. Faktor eksternal itu sendiri dapat menjadikan ancaman untuk kapasitas sumber daya yang dapat berpengaruh terhadap kualitas informasi laporan keuangan, seperti kurangnya pemahaman sumber daya manusia terhadap tren teknologi informasi dan terjadinya perubahan standar pelaporan dapat mengurangi kualitas laporan keuangan, karena kapasitas sumber daya manusia tidak memanfaatkan teknologi informasi dengan baik. Jika bisa memanfaatkan teknologi informasi, karyawan dapat dengan mudah membuat laporan keuangan walaupun ada perubahan standar pelaporan, hal itu masih dapat mengejar dan menghemat waktu untuk membetulkannya.

\section{SIMPULAN Simpulan}

Berdasarkan hasil penelitian dapat disimpulkan sebagai berikut: 1) Sistem pengendalian intern tidak berpengaruh secara signifikan terhadap kualitas informasi laporan keuangan. 2) Kapasitas sumber daya manusia berpengaruh secara signifikan terhadap kualitas informasi laporan keuangan. 3) Faktor eksternal dapat digunakan sebagai pemoderasi pengaruh sistem pengendalian intern terhadap kualitas informasi laporan keuangan. 4) Faktor ekster- nal tidak dapat digunakan sebagai pemoderasi pengaruh kualitas sumber daya manusia terhadap kualitas informasi laporan keuangan.

\section{Keterbatasan}

Berdasarkan penelitian ini, peneliti menemukan keterbatasan dalam penelitian ini antara lain: 1) Penelitian ini dilakukan hanya di Dinas Sosial Daerah Istimewa Yogyakarta, sehingga hasil penelitian belum dapat digeneralisir ke semua objek. 2) Kurangnya pemahaman dari responden terhadap pertanyaanpertanyaan dalam kuisioner serta sikap kepedulian dan keseriusan dalam menjawab semua pertanyaan-pertanyaan yang ada. Masalah subjektivitas dari responden dapat mengakibatkan hasil penelitian ini rentan terhadap biasnya jawaban responden. 3) Variabel bebas yang dimasukkan dalam penelitian ini masih terbatas, tidak semua isu yang menjadi trend topik terkait kualitas informasi laporan keuangan.

\section{Saran Kajian Mendatang}

Berdasarkan keterbatasan diatas peneliti memberi saran sebagai berikut: 1) Mengharapkan untuk penelitian selanjutnya lebih bisa memperluas cakupan penelitiannya, misalnya meneliti pada beberapa instansi di DIY atau beberapa propinsi, beberapa instansi di DIY atau beberapa instansi. 2) Memilih kuesioner yang dapat dipahami oleh responden, dan peneliti sangat mengharapkan pada saat pembagian kuesioner harap dijelaskan terlebih dahulu sebelum responden mengisi kuesiner agar mendapatkan hasil yang lebih baik. 3) Peneliti juga menginginkan agar peneliti selanjutnya dapat menambah variabel bebas yang mempengaruhi kualitas informasi laporan keuangan misalnya variabel sistem informasi akuntansi.

\section{DAFTAR REFERENSI}

Agoes, S. 2012. Auditing, Buku 1 (edisi keempat). Jakarta: Salemba Empat.

Arfianti, D. 2011. Analisis factor-faktor yang mempengaruhi nilai informasi 
pelaporan keuangan Pemerintah Daerah (Studi pada satuan kerja Perangkat Daerah di Kabupaten Batan. Tesis tidak diterbitkan. Univeristas Diponegoro. Semarang.

Badan Pemeriksa Keuangan RI. 2011. Konsep standar pemeriksaan keuangan negara. Diambil pada 10 Desember 2013, dari www.BPK.co.id.

Choirunisah, F. 2008. Faktor-faktor yang mempengaruhi kualitas informasi laporan keuangan yang dihasilkan sistem akuntansi instansi. Prosiding Konferensi Penelitian Keuangan Sektor Publik II. Badan Litbang Departemen Dalam Negeri bekerjasama dengan Asosiasi Peneliti Keuangan Sektor Publik. Jakarta, hal. 40 - 48.

Ghozali, I. 2011. Aplikasi Analisis Multivariate dengan Program SPSS (edisi ketiga). Semarang: Badan Penerbit Universitas Diponegoro.

Honjiang, X., L. Binshan, dan N. D. Jeretta. 2003. Key issues of accounting Information Quality Management: Australian Case Study, Sistem Informasi Bisnis Departemen. College of Business Administration. Central Michigan University 103 (7): 461 470.

Ikatan Akuntan Publik Indonesia. 2011. Standar Profesional Akuntan Publik, Jakarta: Salemba Empat.

Indriasari, D. 2011. Pengaruh kapasitas sumberdaya manusia, pemanfaatan teknologi informasi, dan pengendalian intern akuntansi terhadap nilai informasi pelaporan keuangan pemerintah daerah (Studi pada Pemerintah Kota
Palembang dan Kabupaten Ogan Hilir), Tesis tidak diterbitkan, Universitas Gajah Mada, Yogyakarta.

Kepmendagri No. 29 Tahun 2002. Pedoman pengurusan, pertanggungjawaban, dan pengawasan keuangan daerah serta tata cara penyusunan APBD, pelaksanaan tata usaha keuangan daerah dan penyusunan perhitungan $A P B D$. Diambil pada 17 Desember 2013, dari http://jdih.bpkp.go.id.

Kontan News. 2010. BPK temukan kasus berindikasi pidana. Diambil pada 20 Desember 2013, dari www.kontan.co.id.

Peraturan Pemerintah No. 60 Tahun 2008. Tentang sistem pengendalian internal pemerintah. Diambil pada 24 Desember 2013, dari http://www.depdagri.go.id.

Undang-undang RI No. 32 Tahun 2004. Tentang Pemerintah Daerah. Diambil pada 19 Maret 2014, dari http://www.kpu.go.id.

Viva News. 2012. BPK Temukan 455 Kasus di Pemerintah Daerah. Diambil pada 19 Januari 2013, dari www.Vivanews.co.id.

Yendrawati, R. 2012. Pengaruh pengefektifan pengendalian intern dan audit intern terhadap pencegahan kecurangan akuntansi. Jurnal Akuntansi dan Teknologi Informasi 11 (1): 18 - 42.

Yendrawati, R. 2013. Pengaruh keadilan organisasi terhadap motivasi melakukan kecurangan dengan kualitas pengendalian internal sebagai variabel moderating. Jurnal Inovasi dan Kewirausahaan 3 (1): 49 - 59. 